\title{
The Relationship of Educational Supervision Supervisory Knowledge to Guidance and Labor Education Teacher Motivation Work in the Madrasah Aliyah Jambi City
}

\author{
Muhammad Ridwan ${ }^{1}$, Nurzila $^{2}$, Abdullah Saman ${ }^{3}$, Maisah $^{4}$ \\ ${ }^{1,2,3}$ Doctor Candidate in Institute Agama Islam NegeriSulthanThahaSaefuddin (IAIN STS) Jambi \\ ${ }^{4}$ Postgraduate Lecture in Institute Agama Islam NegeriSulthanThahaSaefuddin (IAIN STS) Jambi
}

\begin{abstract}
One of the educational component is very important in improving the quality of education is a supervisor and teacher. Although these two components have the same duties and functions, but both have an attachment and a clear link and close. To ensure the quality of the learning process in classes conducted by teachers, the supervisor has a very important role is to supervise the activities of the learning process. Quantitative research with the survey method involves 52 supervisors and 102 teachers. Data were analyzed using correlation test, the correlation between the knowledge of the regulatory supervision $(X)$ on the ability of teachers coaching (Y1) and increased work motivation of teachers (Y2). Based on data and discuss as described above, we can conclude the following matters: (a). Knowledge of the regulatory supervision Madrasah Aliyah in Jambi city average in the category of "good / moderate" is as much as 78.38\%. That means, the implementation of the guiding teachers in the school to run well, (b) There is a significant correlation between the knowledge of the regulatory supervision of the teacher training variables with significant correlation level and (c). There is a significant correlation between the variables knowledge of the regulatory supervision of the independent variable is the level of motivation working with significant correlation. $b$. A significant correlation between the knowledge of the regulatory supervision of the teacher coaching Madrasah Aliyah in Jambi, indicating that supervisors should develop coaching programs are more systematic, integrated, directed and continuous in order to improve the quality of education.
\end{abstract}

Keywords: knowledge of the regulatory supervision, supervisor, teacher, Madrasah Aliyah

\section{Introduction}

Prosperity, welfare and human technological progress is directly proportional to education. The better the quality of education process experienced, the level of prosperity, welfare and technological progress, the better. Thus, it can be said that education is a human effort to improve the quality of life. with good process and quality education, human life will also be improved. Therefore, education is an integral part of human life, and to improve the quality of human life, it takes a quality education.

To improve the quality of education is not easy, it requires serious effort, systematic and sustained. One effort that can be done to improve the quality of education is to improve and maintain the quality of teachers. Qualified teachers will ensure the process of education in schools (in the classroom) is maintained. Teachers are the spearheads in the educational process. The existence of teachers in schools cannot be replaced by anything. Therefore, improving the quality of education should start up of upgrading and maintaining teachers quality.

To maintain the quality of teachers in a school or other educational institution required a supervisor who also qualified. Task supervisors and teachers are closely related to human resource development. Supervisors are professional, have a high knowledge of supervision is needed to guide and nurture them to become professional teachers in carrying out the teacher tasks. Therefore, to become professional teachers needed guidance and coaching is a systematic, integrated and continuous professional supervisors from the well.

Referring to the above description can be understood that the teacher is an important and integral part in improving the quality of education. Therefore, coaching and guidance through continuous supervision activities necessary to ensure the professionalism of teachers is maintained, so that the teacher's ability to manage activities guaranteed quality of teaching in schools.

To ensure the quality of the learning process in classes conducted by teachers, supervisors as a supervisor has a very important role is to supervise the activities of the learning process. This is in accordance with the Burn (2011) that one of the educators who serves as supervisor, who has the task of fostering and guiding teachers of religion in schools Madrasah, is superintendent.

Related to education supervisors, Amatembun in Syaeful Sagala (2011), educational supervision is the development towards improving the educational situation. As according to Purwanto (2002) supervision is a coaching activity planned to help teachers and other school personnel to do their jobs effectively.

In line with the above opinion, Engkoswara and Komariah (2011) states that the surveillance conducted by the experts/ professionals in the field so as to provide repair and improvement/ coaching for learning can be done well and with quality. Pidarta (1992) adds that the nature of the 


\section{International Journal of Science and Research (IJSR) \\ ISSN (Online): 2319-7064 \\ Index Copernicus Value (2013): 6.14 | Impact Factor (2015): 6.391}

supervision of a guardianship of party bosses to teachers and the personnel of the school more directly address the students' learning, to improve teaching and learning situation, so that students can learn effectively with student achievement increases. As for the team Lecturer AP, UPI (2008), the nature of education supervisors be construed as professional guidance for teachers, the effort provides an opportunity for teachers to grow professionally, so they are more advanced in implementing the main task, which is to improve and increase the learning process of students.

Based on those opinions can be concluded that the educational supervision is overseen by a professional coaching and guidance to teachers from an expert /professional to provide the opportunity for teachers to grow professionally, so as to improve the teaching situation in order to increase learners' achievements. Moreover, from an understanding of the foregoing, it can be seen there are three main points that cover in terms of supervision are: (a) supervision is the provision of services and assistance to the staff of the school/madrasah to improve the quality of teaching and learning. (b) The activities of supervision are always related to the performance of teachers in teaching and learning as evidenced by student learning outcomes (c) supervision activities carried out by the supervisor (Principal/Madrasah School/Madrasah and other coaches).

Associated with the duties of a supervisor, Physical and Mustafa (2013) explains that the task of education supervisors associated with the assistance and guidance of the teachers at the school include: (1) help teachers to understand the nature and character of students, (2) to assist teachers in developing and improving lesson plan that will be used, either individually or in groups, (3) help the entire staff of the teaching workforce in order to increase the effectiveness of the learning process to be implemented, (4) help teachers to understand learning theory to improve the teaching skills of teachers so that the learning process more effective , (5) to assist and evaluate the ability of teachers in terms of assessing learners, (6) directs and encourages teachers to do a self-assessment in carrying out their duties honestly, (7) to encourage and assist teachers in understanding and implementing the curriculum in schools, and (8 ) encourage teachers to participate actively in progress convey information related to the school or educational institution where she worked.

Based on the descriptions above it can be concluded that the duties and responsibilities of supervisors as supervisor who supervises the academic and managerial supervision that includes monitoring /monitoring, supervision, assessment, training/ professional development, and quality assurance. Supervision activities is the development of the regulatory activities for teachers. Thus, in its supervisory activities, the supervisor provides assistance in the form of professional guidance to improve the professionalism of teachers in the work. In this case, supervision is a function of providing direct assistance to teachers to enhance the learning process. Additionally, to enhance the learning supervisor has the duty and the responsibility to develop the group, to develop the professionalism of teachers, developing curriculum, and encourage teachers to conduct action research.
According Arikunto (2006) the purpose of supervision can be grouped into two categories, namely general purpose and special purpose. The general objective of supervision activities is to provide technical assistance and guidance to teachers and other staff in order to improve the quality of performance in carrying out the task of learning at school. As for the specific purpose of a supervision activities are: (a) to boost the performance of learners (students), (b) to help the teacher to actively improve its performance that is guiding learners to achieve optimal, (c) to ensure curriculum achievement in schools, so that graduates of the institution in accordance with expectations, (d) to encourage and ensure the use of all facilities and infrastructure applied effectively and efficiently to maximize student learning outcomes, (e) to support and ensure a learning environment that is conducive to learning.

Based on the above opinion, it can be concluded that the supervision activities carried out by the supervisor has the aim of providing assistance to school personnel, including teachers, to improve its performance by fixing errors, deficiencies and help solve the problem in order to achieve effectiveness and efficiency of teaching and learning so that learners' achievements increases. In short, the supervision carried out by the supervisory function and aims to conduct guidance and supervision of school personnel (principals and teachers).

Based on the above description, illustrated clearly that, supervision activities are very important to do. Research conducted by Apriliana (2015) proved that there was a significant influence between supervisionsupervisors on teacher performance to the level reach of $14.1 \%$ influence. In addition, the supervisor also supervision influence on job satisfaction of teachers and the working relationship among teachers. The findings prove that supervision slight positive impact on improving the quality of education.

Supervision and guidance activities undertaken by the supervisor, should be in accordance with the needs of teachers. Supervision and coaching that does not conform to the needs of teachers make less attractive development activities by teachers. As according Fathurrohman and Suryana (2011) that the aid is not in accordance with the needs of teachers if it is not rejected such assistance less attractive and appreciated by teachers and is considered as an activity that interfere with the activities of teachers. It will indirectly bring an attitude like lazy or simply assume supervision routines and formalities. Meanwhile, supervision and coaching is right on target can increase the motivation and performance of teachers. This is consistent with research daughter and Muchtar (2013) and Purwaningsih, (2012) which concluded that the supervision of the supervisory significant and positive impact on work motivation.

Referring to the above description can be understood that the supervision and the right coaching and adequate urgently needed to improve the quality of the learning process. Therefore, if the supervision and coaching is done by a school supervisor is not adequate, then the quality of the learning process that teachers do in the classroom is also inadequate. It is as presented by Sagala (2010) that one of 


\section{International Journal of Science and Research (IJSR) \\ ISSN (Online): 2319-7064 \\ Index Copernicus Value (2013): 6.14 | Impact Factor (2015): 6.391}

the factors causing low professionalism of teachers is inadequate support supervision carried out by supervisors.

Related to the above issues, a lady supervisor is required to have extensive knowledge and insight as well as having particular competence. Breadth of knowledge and insight as well as the competence of the supervisory will greatly impact his ability to perform his duties as a supervisor. Competency a supervisor has been written in the National Education Minister Regulation number 12 of 2007, which is about the standard of school /madrasah inspectors. In the regulation explains that a supervisor should have the educational qualifications and adequate competence. The competencies required by Education Ministerregulation are: (1) personal competence, competence include: responsibility as a supervisor, have the creativity in the work, has a curiosity for a variety of changes and advances in the field of education and have the motivation to work tall one. (2) the competence of supervision managerial, competencies include: the ability in terms of mastering the methods, techniques and principles-principles requires supervision to improve the quality of education, able to devise programs of supervision appropriately and accurately and prepare reports supervisory, ability in terms of fostering the principal, teachers and other education staff, monitor the implementation of educational standards set by the government. (3) the competence of the academic supervision, these competencies include: understanding the supervisor of the concepts, principles, basic theory, the characteristics of each subject and ability in guiding teachers in preparing and developing the syllabus, define models/methods/learning strategies appropriate, laboratory activities, and so on, (4) competency evaluation of education, competencies include: the supervisor ability in makes up the criteria and indicators of the success of education and the learning process, the ability to guide teachers and principals to prepare instruments and carry out an assessment capabilities in terms of overseeing the implementation of assessment by teachers and principals and so forth. (5) Research and development competencies, these competencies include: the ability in terms of control of various types and methods in education, compile research proposals and conduct research, process data and to report the results in the form scientific research and so on.

Based on the descriptions above, it was clear that the insight, breadth of knowledge requirements sufficient competence is an absolute requirement for a school watchdogs/madrasah.
However, in practice, the appointment of inspectors in the city of Jambi has not been based on the terms above. This is evident by the lack of specific tests conducted by the government in the appointment of school inspectors. As for the appointment of school inspectors are still based on the needs and the submission of the candidate's own watchdog. This fact of course have an impact on the quality watchdog itself. Therefore, the focus of this research is how the knowledge of educational supervision watchdog and its relationship to the ability of supervisors in fostering increased motivation of teachers and teacher work.

\section{Method}

This research is a quantitative research. The study is divided into several stages, namely the planning phase, the implementation phase, the stage of completion. The subjects of this study were all supervisors and teachers Madrasah Aliyah in Jambi. Data collection techniques in this study using questionnaire techniques (questionnaire), with a survey method. Data obtained in the form of numbers. Data were analyzed using correlation test, the correlation between the knowledge of the regulatory supervision $(\mathrm{X})$ on the ability of teachers coaching (Y1) and increased work motivation of teachers (Y2). To find out how strong (significance) of correlation test $\mathrm{T}$ and $\mathrm{F}$ test entire statistical tests performed with SPSS version. 20.

\section{Data and Discussion}

\subsection{Profile Knowledge Supervisory Madrasah Aliyah in Jambi}

The results of a survey involving 52 supervisors Madrasah Aliyah in Jambi shows that the average knowledge of the regulatory supervision categorized as "Moderate / good". In general, the survey results can be seen in Figure 1 below:

Table 1: Percentage of Category Knowledge supervisor

\begin{tabular}{|c|c|c|}
\hline \multicolumn{3}{|c|}{ Supervision } \\
\hline Category (Score) & Total Respondents & $\%$ \\
\hline Low $(<60$ & 10 & 27,03 \\
\hline Medium $(60 \leq$ score $\leq 80)$ & 29 & 78,38 \\
\hline High $(>81)$ & 13 & 35,14 \\
\hline Total & 52 & 100 \\
\hline
\end{tabular}

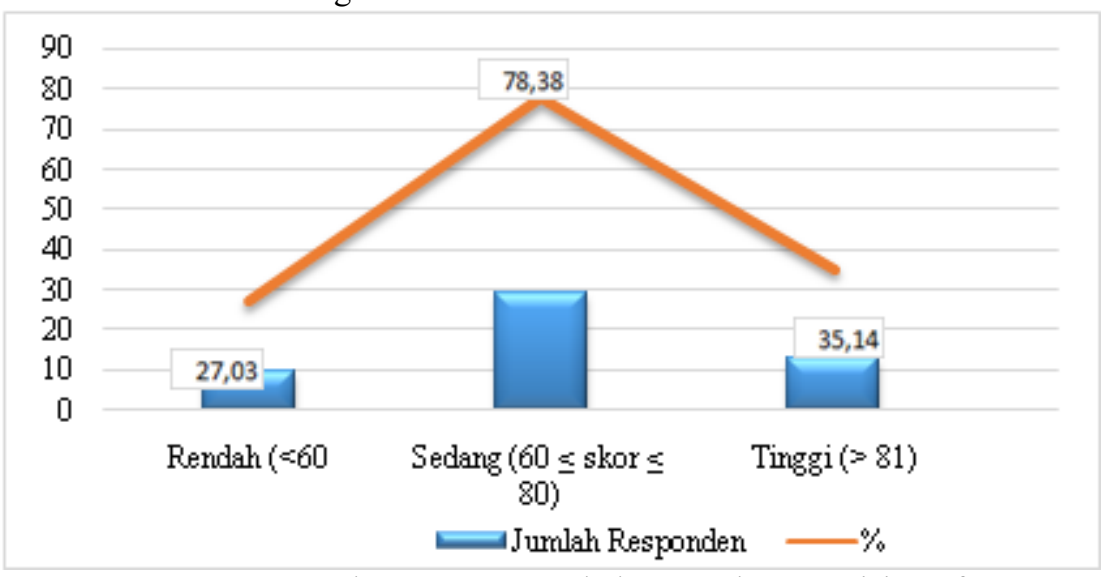

Figure 1: Percentage and category Knowledge Graph Supervision of Trustees

\section{Volume 5 Issue 8, August 2016 www.ijsr.net}




\section{International Journal of Science and Research (IJSR) \\ ISSN (Online): 2319-7064 \\ Index Copernicus Value (2013): 6.14 | Impact Factor (2015): 6.391}

Based on Table 1 and Figure 1 above shows that knowledge of the regulatory supervision of Madrasah Aliyah in Jambi, dominated by supervisors with the knowledge supervision categorized as "moderate/good". That means, in general superintendent Madrasah Aliyah in Jambi have social competence, managerial, personable and professional "medium". In other words, there are still some unknown supervision competencies and mastered by the Madrasah Aliyah supervisor in Jambi.

As has been outlined above, according to the physical and Mustafa (2013) that the job of a supervisor is to help teachers to understand the characteristics of learners, helping teachers in resolving issues related to implementation of the tasks of teachers, encourages and helps the entire staff at the school in order to support and implement educational programs more effectively and help teachers to make them more effective in their duties. Therefore, supervisor Madrasah Aliyah in Jambi need to improve knowledge of the regulatory supervision to support the implementation of their tasks.

In addition, increased knowledge of supervision for supervisors is also a must. Supervision on ignorance watchers will have an impact on the quality of the coaching supervisor's to service and teachers. It is as presented by Sagala (2010) that one of the factors causing low professionalism of teachers is inadequate support supervision carried out by supervisors. The poor of knowledge supervision may also have an impact on the refusal by the teachers as the opinion of Fathurrohman and Suryana (2011) that the aid is not in accordance with the needs of teachers will be rejected or less attractive and appreciated by teachers and are considered as activities that disrupt the activities of teachers.

\subsection{Against the influence of knowledge Supervision Supervisory capability of Teachers guidance in Madrasah Aliyah in Jambi}

Table 2: Correlations Test (X Vs Y1)

\begin{tabular}{|c|c|c|c|}
\hline \multicolumn{2}{|c|}{} & $\begin{array}{c}\text { Knowledge } \\
\text { Supervision }\end{array}$ & $\begin{array}{c}\text { Teachers } \\
\text { Guidance }\end{array}$ \\
\hline \multirow{2}{*}{$\begin{array}{l}\text { Knowledge } \\
\text { Supervision }\end{array}$} & Pearson Correlation & 1 &, $629^{* *}$ \\
\cline { 2 - 4 } & Sig. (2-tailed) & &, 000 \\
\cline { 2 - 4 } & $\mathrm{N}$ & 52 & 52 \\
\hline \multirow{2}{*}{$\begin{array}{c}\text { Teachers } \\
\text { Guidance }\end{array}$} & Pearson Correlation &, $629^{* *}$ & 1 \\
\cline { 2 - 4 } & Sig. (2-tailed) &, 000 & \\
\cline { 2 - 4 } & $\mathrm{N}$ & 52 & 52 \\
\hline \multirow{2}{*}{$* *$ Correlation is significant at the 0.01 level (2-tailed). } \\
\hline
\end{tabular}

Based on Table 1, namely Correlations Test (X Vs Y1) can be seen that the significant value of 0.629 with values obtained probabilityy Sig. (2-tailed) her 0,000. The probabilityy the value $<0.05$. Thus, there is a significant correlation between the knowledge of the regulatory supervision of the teacher training variables. In addition, under an asterisk (SPSS output) is seen between the two variables have two stars, it shows that both variables have a significant correlation.

The findings of the above results show that knowledge of supervision for supervisors, particularly supervisors at Madrasah Aliyah in Jambi is a very important thing. The high knowledge of the supervision of the supervisor will be followed by supervisors in the high ability to provide guidance to teachers, and vice versa. Thus it can be understood that in order to improve the quality of education can be done by improving the quality inspectors. With the quality supervision watchdog good knowledge, supervisors will be able to carry out the task of supervising teachers will also be better. While teachers are nurtured properly, would be able to perform the duties of teacher well anyway so that the quality of education services will increase.

As the opinion of Fuel (2011) that one of the educators who serves as supervisor, who has the task of fostering and guiding teachers of religion in schools / Madrasah, is the supervisor, the supervisor proactively required to always try to improve knowledge of supervision. Nurture and guide the activities of teachers is the main task of a supervisor, the supervision of knowledge related to the formation of teachers is the main thing. Therefore, increased knowledge of the watchdog supervision can be done formally (improvement of educational qualifications of Master and Doctoral) and informally, through discussions among supervisors.

Based on the explanation of Tim Lecturer AP, UPI (2008) that the essence of education supervisors be construed as professional guidance for teachers, the effort provides an opportunity for teachers to grow professionally, so they are more advanced in implementing the main task, which is to improve and enhance the learning process of students. Therefore it is clear that improving the knowledge supervision of supervisors, process guidance and coaching professionals to be going to run better.

3.3. The influence of the regulatory supervision of knowledge on work motivation of teachers in Madrasah Aliyah in Jambi

Table 3: Correlations Test (X Vs Y2)

\begin{tabular}{|c|c|c|c|}
\hline & & $\begin{array}{c}\text { Knowledge of } \\
\text { supervisor }\end{array}$ & $\begin{array}{c}\text { Work } \\
\text { motivation }\end{array}$ \\
\hline \multirow{3}{*}{$\begin{array}{l}\text { Knowledge of } \\
\text { supervisor }\end{array}$} & Pearson Correlation & 1 &, $580^{* *}$ \\
\hline & \begin{tabular}{|l|} 
Sig. (2-tailed) \\
\end{tabular} & &, 000 \\
\hline & $\mathrm{N}$ & 52 & 52 \\
\hline \multirow{3}{*}{$\begin{array}{c}\text { Work } \\
\text { motivation }\end{array}$} & Pearson Correlation &, $580^{* *}$ & 1 \\
\hline & \begin{tabular}{|l|} 
Sig. (2-tailed) \\
\end{tabular} &, 000 & \\
\hline & $\mathrm{N}$ & 52 & 52 \\
\hline
\end{tabular}

Based on Table 3. Correlations Test (X Vs Y2) can be seen that the significant value of 0.580 with values obtained probability Sig. (2-tailed) her 0,000 . The probability the value $<0.05$. Thus, there is a significant correlation between the variables knowledge of the regulatory supervision of the independent variable is motivation Work. In addition, under an asterisk (SPSS output) is seen between the two variables have two stars, it shows that both variables have a significant correlation.

The strong correlation between knowledge of the regulatory supervision of the teacher work showed increased motivation take the role of a supervisor in increasing job motivation of teachers is an important point. Supervisors

\section{Volume 5 Issue 8, August 2016}




\section{International Journal of Science and Research (IJSR) \\ ISSN (Online): 2319-7064}

Index Copernicus Value (2013): 6.14 | Impact Factor (2015): 6.391

were professional (supervision knowledgeable high) will be able to increase the motivation of teachers is better than the inspectors who have professional (low knowledge of supervisory). In other words it can be said that the teacher work motivation is influenced by the ability of the supervisor to guide and nurture the teacher at the time of supervision activities. This is consistent with research daughter and Muchtar (2013) and Purwaningsih, (2012) which concluded that the supervision of the supervisory significant and positive impact on work motivation

Trustees with good knowledge and high supervision will have good skills also in the conduct guidance and coaching. Thus the guidance and the guidance given by supervisors to be more on target so it is more easily accepted and implemented by the teachers. With the receipt of the regulatory guidance and coaching for teachers, will lead to motivation of teachers to follow the process of coaching is done by inspectors. In short supervision and coaching is right on target can increase the motivation and performance of teachers.

\section{Conclusions and Recommendations}

\subsection{Conclusion}

Based on data and discuss as described above, we can conclude the following matters:

a) Knowledge of the regulatory supervision Madasarah Aliyah in Jambi city average in the category of "good / moderate" is as much as $78.38 \%$. That means, the implementation of the guidance teachers in the school to run well.

b) There is a significant correlation between the knowledge of the regulatory supervision of the teacher training variables with significant correlation level.

c) There is a significant correlation between the variables knowledge of the regulatory supervision of the independent variable is the level of motivation working with significant correlation.

\subsection{Recommendations}

Based on thediscuss and conclusions obtained, some of the suggestions put forward in this study are as follows:

a) With an average knowledge of supervision in the category of "moderate/good", it shows that there is still need for development and improvement of knowledge of the regulatory supervision. It aims to make demands that are required in the regulations of the minister of education as described above.

b) A significant correlation between the knowledge of the regulatory supervision of the teacher coaching Madrasah Aliyah in Jambi, indicating that supervisors should develop coaching programs are more systematic, integrated, directed and continuous in order to improve the quality of education.

c) In addition, coaching of teachers by supervisors as suggestions in point $b$ above, the supervision and guidance, should the supervisor Madrasah Aliyah need to develop a pattern formation humanist to trigger and stimulate the spirit / work motivation of the teachers, so teachers have high motivation. Moreover, the pattern of development of humane by the supervisor for teachers to foster a harmonious relationship between supervisors and teachers.

\section{References}

[1] Ali Imron. (2011). SupervisiPembelajaran Tingkat SatuanPendidikan. Jakarta: BumiAksara.

[2] Arikunto, S. (2002). ProsedurPenelitian, suatupendekaranPraktik, Jakarta, RinekaCipta.

[3] Arikunto, S. (2006) Dasar-dasarsupervisi. Jakarta. RinekaCipta.

[4] Bahri, Syamsul. (2011). Faktor yang MempengaruhiKinerja Guru SD di DataranTinggimoncongKabupatenGowaProvinsi Sulawesi Selatan. JurnalMEDTEK, Vol 3 Nomor 2.

[5] Bakar, Abu (2011).SupervisiPendidikan Agama Islam. (PembinaanGuru Agama Madrasah/ Sekolah). JurnalSosialBudaya, Vol. 8 No. 01 Januari - Juni 2011

[6] Engkoswara\&AanKomariah. AdministrasiPendidikan. Bandung: Alfabeta.

(2011).

[7] Glickman, Carl D., Stephen P. Gordon, \&Jovita M. Ross-Gordon. (2010). Supervision and Instructional Leadership a Developmental Approach. Ninth Edition. New Jersey: Pearson Education, Inc.

[8] Hamzah (2011).TeoriMotivasidanPengukurannyaAnalisis B., BidangPendidikan, Jakarta: PT BumiAksara.

[9] JasmaniAsf\&SyaifulMustofa. SupervisiPendidikanTerobosanBarudalamPeningkatan KinerjaPengawasSekolahdan Guru. Yogyakarta: ArRuzz Media.

[10] Judge, Timothy A., et al. (1998). Dispotional Effects on Job and Life Satistaction: The Role of Core Evalution. Journal of Applied Psycology Vol. 83, No.1, 17-34. America: American Psycological Association, Inc.

[11] Mukhtar, (2009), OrientasiBaruSupervisiPendidikan, Jakarta : GP Press

[12] Mendiknas. PeraturanMenteriPendidikanNasionalNomor 12 Tahun 2007 tentangStandarPengawasSekolah/ Madrasah.

[13] Mohanty, Jagannath. (2005). Educational Administration, Supervision and School Management, 2nd Ed and Enlarged Edition. New Delhi: Deep \& Deep Publication (P) Ltd

[14]Pidarta, Made PemikirantentangSupervisiPendidikan.

(1992) BumiAksara

[15] Purwanto, M. Ngalim. (2002). AdministrasidanSupervisiPendidikan, Bandung: RemajaRosdaKarya

[16] Purwaningsih, Happy. PengaruhSupervisiKepalaSekolahdanMotivasiKerja Guru TerhadapKinerjaGuruekonomi/Akuntansi SMA/MA/SMK Di Kota Pekalongan. Skripsi. UniversitasNegeri Semarang

[17] PupuhFathurrohmandanSuryana. (2011).SupervisiPendidikandalamPengembangan Proses Pengajaran. Bandung: RefikaAditama.

[18] Sagala, Syaeful. (20110. KemampuanPrifesional Guru danTenagaKependidikan, Bandung. CV. Afabeta.

[19] Suharsaputra, Umar,(2010).AdministrasiPendidikan, Bandung: PT. RefikaAditama 


\section{International Journal of Science and Research (IJSR) \\ ISSN (Online): 2319-7064}

Index Copernicus Value (2013): 6.14 | Impact Factor (2015): 6.391

[20] Tim Dosen AP UPI. (2008). ManajemenPendidikan. Bandung: Alfabeta.

[21] Yamin, Martinis, (2010).StandarisasiKinerja Guru, Jakarta: GP Press

[22] PutridanMuchtar (2013). PengaruhSupervisiPengawas, LingkunganKerja Dan MotivasiKerjaterhadapKinerja Guru Ekonomi di SMA/MA Kota Solok, Journal Pendidikan.

Volume 5 Issue 8, August 2016 www.ijsr.net 